\title{
Theoretical reflections on narrative in action research.
}

TOLEDANO, N. and ANDERSON, A.R.

2020

(c) [2017] (Authors). 


\title{
Theoretical reflections on narrative in action research
}

\author{
Nuria Toledano \\ University of Huelva, Spain
}

toledano@dem.uhu.es

\section{Alistair R Anderson \\ Robert Gordon University, Aberdeen}

a.r.anderson@rgu.ac.uk

\begin{abstract}
Narrative is an important tool for developing and writing up action research experiences. Its power lies in the fact that narrative construction and narrative recounting are fundamental human communication practices. Narratives are also knowledge producing devices, since they make sense of personal experiences and share that sense-giving with others. However, the twinned duality of narrative knowing (sense-making) and narrative telling (communicating that sense) has often caused narrative as a methodological approach to be disregarded or misunderstood. Our objective is to reflect on how we can best use the narrative method in action research by paying due attention to these issues. In doing so, we consider ontologies, epistemologies and key characteristics. We argue that what has been seen as a weakness in the narrative method, its deep subjectivity, can actually be employed as an analytical strength in action research. We show how examining explanations of context, inherent in narrative processes, can provide rich insights into the meanings of phenomena.
\end{abstract}

Keywords

Action research, narrative method, narrative knowing, narrative telling, qualitative research

\section{Introduction}

Action research is gaining recognition for opening new avenues to the way we approach investigations. Such interest was first evidenced only recently (Greenwood \& Levin, 2007). Nevertheless, action research has a long tradition 
that goes back to the philosophical and educational works of John Dewey (18591952). Indeed, action research is concerned with developing practical knowledge from a wide variety of fields, and their approaches can even be found in the Catholic Action movement and liberation theology (Brydon-Miller, Greenwood,

\& Maguire, 2003).

Efforts to explore the history of action research have shed light on its multiple

origins (Boog, 2003; Hockley, Froggatt, \& Heimerl, 2013; Stokols, 2006). However, there is no one unique coherent tale on which to focus. Many researchers acknowledge Kurt Lewin as a key pioneer in the development of action research. To him, credit is given for advocating democratic and collaborative ways of working with community practitioners to ameliorate societal problems (Adelman, 1993; Burnes, 2004; Schein, 1996). Others also see the origins of action research in the works of Jacob Moreno (Greenwood, 2015; Gunz, 1996). His efforts to stimulate the integration of theory, research and practice are praised as much as his perception of the role of the investigator as "co-operator" and research subjects as "co-actors" (Gunz, 1996). There are, of course, other names (e.g. Gregory Bateson, John Collier), but what we mainly see in all of them is a twofold concern: first, the fact that theory cannot be separated from practice, so that action research takes place in context (Rauch, Schuster, Stern, Pribila, \& Townsend, 2014; Somekh, 2006); second, people's involvement is necessary to achieve consolidated learning and social change, and action research thus adopts a participative approach to knowledge creation (Bradbury, 2015; McTaggart, 1994; Reason \& Torbert, 2001).

In the social sciences, interest in action research is growing in great part due to its sheer participative and democratic power. It is seen as a way to revitalize our studies in this field by taking into account, in a collaborative way, the changes that happen in our lives and in the world around us (Grant \& Ken, 2016; Pettit, 2010). In fact, the point of action research is that change is not just an abstract construct. Rather, it is a primary purpose among the "co-actors" of the investigation, so that what matters is how actual participants acted, learned, hoped or despaired, and, most important, changed (Walker, 2007). For example, participants such as organ-izational members, stakeholders or communities come together along with the researcher in search of understanding, improvement, and practical solutions that change situations of pressing concern to them (Greenwood \& Levin, 2007; Reason

\& Bradbury, 2001).

Collaborative reflection invites narratives to occupy a central place in action research practices (Eriksson \& Kovalainen, 2015; Pushar \& Clandinin, 2009; Walker, 2007). Gergen and Gergen (1988) argue that narrative is a major means by which we make ourselves intelligible to each other. Previously, Fisher (1984, p. 1) had described "man" as "homo narrus", whilst MacIntyre (1981, p. 201) had recognized that "man is in his actions, as well as his fictions, essentially a story telling animal". Prior to all of them, Hardy (1968, p. 6) had already noted that "we dream, remember, hope, despair and even love and hate in narratives". Hence, without narrative, it would be almost impossible to work collaboratively. 
As a fundamental form of human communication, narratives are exceptional in how they both "know and tell". The narrative concept relates the meaning-making and translation process of people's knowledge to an understandable telling (White, 1980). This is important because knowledge is often implicit and enclosed in every-day existence; but narratives help explain that knowledge by relating people's experiences in common social contexts (Bruner, 1991). Nonetheless, the fact that narratives are common tools that human beings employ in their daily interactions has led to their neglect as a methodological approach. Most conventional social scientists consider narratives to be incomprehensible, uncontrollable, trivial, and probably just a little scary (Greenwood \& Levin, 2007). In fact, as a method, narrative remains somewhat contentious (Boje, 2011; Czarniawska, 2007), with some authors expressing concerns about their practical application (Grobstein, 2005). It is this methodological application that occasions the research problem that we address in this paper.

Our objective is to reflect on how we can best use the narrative method in action research by paying due attention to the main issues in the process of narrative knowing (making) and narrative telling (communicating). Our conceptual point of departure is narrative as "method". However, we also remain mindful of narrative as a natural human activity and "phenomenon" (Clandinin \& Connelly, 1991). As Barthes (1977) puts it, there has never been "a people" without a narrative, but the ubiquity, the sheer commonplaceness of narrative, masks complexity. For research purposes, we need to reach below the surface to examine the duality of knowing and telling. Indeed, we must understand narratives' form and function, so that we can use them appropriately as method in action research. This paper addresses these issues. We begin by considering frames that can affect the methodological use of narratives, in particular, their ontological and epistemological status. We then describe the key aspects of narrative as a method and stress their benefits to action research. After that, we review narrative strengths and weaknesses by comparing them with traditional research methodology. Finally, we conclude by discussing how the potential of narrative as method can be recognized in action research.

\section{The epistemological and ontological status of narrative}

Because the narrative method places personal experiences at the heart of research, the epistemology is knowledge about experience. Narrative epistemology can thus be viewed as the ways in which individuals enact and represent their meanings and understandings of their life worlds through their personal experiences (past, on-going or future). This "knowing" about their personal worlds also reveals different assumptions about ontology (Muncey, 2010), which can help us develop a better understanding of the different applications of the narrative method. A narrative perspective is underpinned by the belief that realities are multiple and constructed (Lincoln \& Guba, 1985), but the ontological question is whether this reality is internal or external to the individual. Moreover, the duality of narrative as both a form of understanding - knowing - and a form of discourse - telling - raises some 
interesting points. However, whilst narrative telling - writing - has been clearly acknowledged as a natural way of providing action research reports (Attard, 2012), some aspects of narrative knowing deserve special attention - for example, the sheer versatility of narrative use in language whilst gaining experiential knowledge. Nevertheless, an analysis of the relationship between language and cognition at a more general level remains outside the scope of this article. Therefore, our main concern is to focus on discussions that can help us illuminate the strengths of the narrative approach in action research.

Seen from this perspective, we can begin to discern how narrative as a meaning making process - narrative knowing - engages a constructionist view of reality. The broad shift from the empirical object of representation ("the facts") to the vehicle of representation (narrative) defines the constructionist paradigm. In this view, the social world evokes a continuous process that is created afresh in each encounter of everyday life, as individuals impose themselves on their world to establish a realm of meaningful definitions. A constructionist social reality is embedded in the nature and use of modes of symbolic action (Morgan \& Smircich, 1980). The realm of social affairs thus has no concrete status of any kind; it is a symbolic construction. Symbolic modes of being in the world, such as those forms through which some believers experience their relationship with God, may result in the development of shared and multiple realities (Swidler, 1986).

Conversely, if we shift from narrative as meaning making to the communication process through which meanings are shared - narrative telling - the core ontology changes towards reality as symbolic discourse. This is because meanings become shared in the process, and consequently, there is a shift to bring milieu and context into closer focus. Morgan (1980) explains how the social world becomes a pattern of symbolic relationships and meanings sustained through a process of human action and interaction. Moreover, this process is always open to reaffirmation or change through the interpretations and actions of individual members. Accordingly, the fundamental character of the social world is embedded in the network of subjective meanings that sustain the rule-like actions that lend it endur-ing form (Morgan \& Smircich, 1980).

Furthermore, when one adopts a complete view of narrative, that is, as both narrative making and narrative telling processes, it is possible to employ a different ontology based on a critical relational constructionism. Figure 1 shows this reconciliation.

A central theme of critical relational constructionism is an emphasis on appreciation and openness. This facilitates the creation of a persuasive connectedness between researchers and key informants and can render narrative one of the most promising vehicles to action research. Leastwise two powerful reasons support such a view. First, as a pragmatic ontology of experiences, this perspective synthesises the representative aspect of narratives with an ontology of being, where narratives create the sense of being in relation, giving relevance to a participatory worldview. Second, and related to this, as a critical relational constructionism ontology, nar-rative centres on the assumption that constructions of persons, worlds, and their 


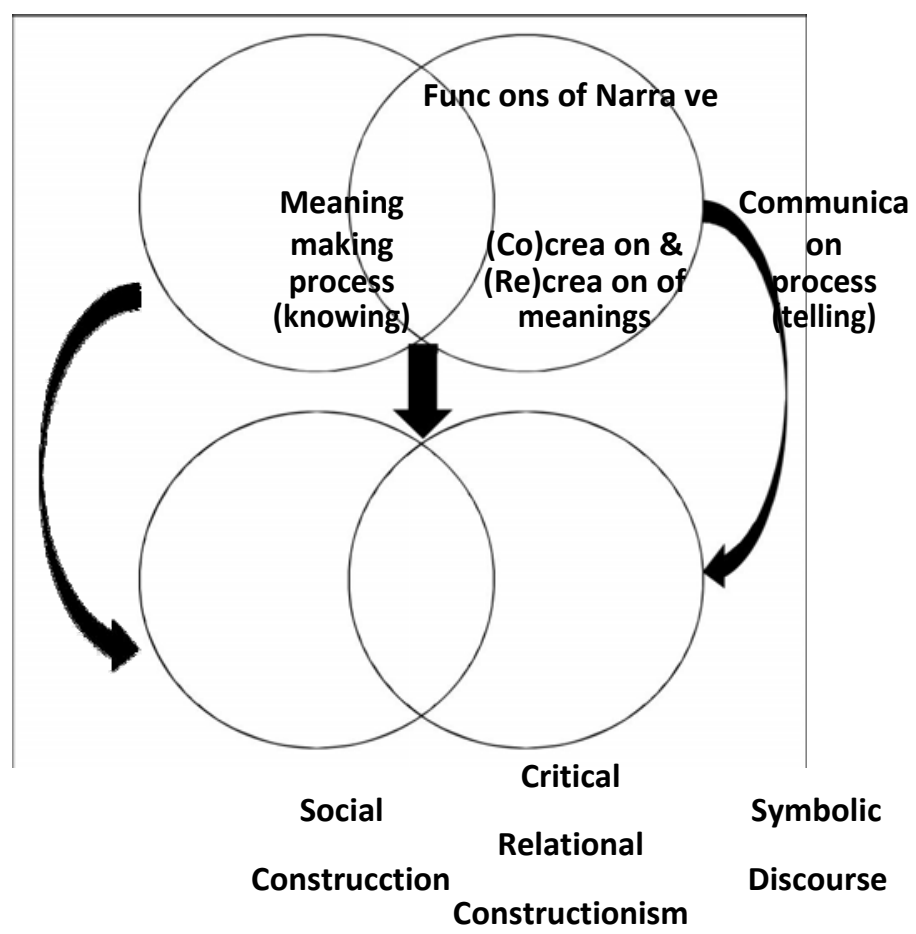

Ontological Assumptions

Figure 1. Functions of narrative and core ontological assumptions about reality.

relations are relational realities (Hosking, 2004). Relations then become significant not just as an instrumental means of achieving some rational ends or world views but for their moment-by-moment openness to, and appreciation of, other possible selves and worlds (Harding, 1986). Given the centrality of the construction pro-cesses, researchers and informants or practitioners, self and others, are viewed as reciprocal co-constructions that participate in on-going processes of research in action. Consequently, narratives are founded in relational processes, always co-created and rarely complete. However, an understanding of what narratives are raises the question of how narratives work; and to this we now turn.

The substance of the narrative as process and method:

Critical elements

In narrative literature, the critical elements are seen to consist of reflexive creation and communication of meanings of experiences through cooperative relationships 
and language, which also imply the consideration of specific times and places (Brockmeier, 2000; Ricoeur, 1984). These elements, in essence, are in close connection with generally recognized principles for validating narratives in action research (Heikkinen, Huttunen, \& Syrja“la“, 2007; Heikkinen, Huttunen, Syrja“la“, \& Pesonen, 2012). Examining such elements - narrative substance - we can understand the workings of narratives in action research (Eriksson \& Kovalainen, 2015) and how action research can take advantage of them. We will analyse this more deeply in the following paragraphs.

\section{Reflexiveness}

Reflexiveness is the practical thinking that emerges from or is produced by the dynamics of the process itself (Scho"n, 1983). This practical thinking or reflection can take place in different forms and at different levels, but in one way or another, it is consubstantial to narratives. Heron (1988), for example, noted that the use of narratives implies three levels of reflection: descriptive reflection on events and our actions and reactions, from our own perspective, to such events; evaluative reflection, in which we critique, judge and respond emotionally to lived experiences; and practical reflection, which guides our future actions. However, regardless of diverse types or levels of reflection, all reflective processes share some common features that should be stressed. First, all reflection is concerned with interpretation, ana-lysis and contemplation of experience (past, present or future) (Bray, Lee, Smith, \& Yorks, 2000). Reflection entails putting together different elements of an experi-ence, including the reasons that events and actions occur (Bruner, 1991), to create tentative patterns of meaning. As a consequence, practical narratives that generate new knowledge or better understandings may emerge (Brockmeier, 2000; Colombo, 2003). Second, reflection entails an evaluation or auto-reflexive process, so that all narrative processes develop, in some manner, a self-narrative or autobiography (Bochner, 2012). Third, all reflective processes involve deliberating on experiences of the self that appear to us as a reflected light from other selves (Muncey, 2010). Therefore, self and society (others) become a common whole within the reflexive element of narrative.

Given these premises, narrative is potentially a valuable tool for the reflective practice embedded in action research (Heikkinen et al., 2007; Leitch \& Day, 2000) in at least two ways. A first way has to do with the development of self-narratives or autobiographies that implies the narrative processes. Such autobiographies may help action researchers engage in meta-reflection on how their actions might influ-ence the research process. Moreover, as action researchers' personal growth is part of the change process pursued by action research (Somekh, 2006), autobiographies may provide an opportunity to contribute to that growth. A second way is related to the intersubjective reflection between self and others inherent in narratives. This kind of reflection might support the participative involvement of practitioners pursued in action research, making of narratives a warranty instrument of the participative orientation. 


\section{Cooperation}

Another defining element of narrative is its essence as a socialized activity (Grobstein, 2005). The narrative method requires the cooperation of others; it demands a conversation partner(s) (Jamal, Bertotti, Lorenc, \& Harden, 2015) to cooperate in the analysis and solving of problems of mutual interest (Greenwood \& Levin, 2007). Narrative research itself becomes a co-creation process in which repeated cycles of action (a personal explanation of one person) and re-action (interpretation of what has been heard from others) (Bray et al., 2000) take place between speaker and listener in cooperative negotiation. They do not act individually or independently; rather, they act jointly as a collective "we" (Shotter, 1984). In this sense, the researcher becomes both co-researcher and co-subject, whilst the subjects of the study join in as co-inquirers rather than simply informants (Heron, 1988).

The idea of a relational narrative is closely connected with the democratic share sought by action research (Pushar \& Clandinin, 2009). Previous work touches on it as the principle of dialectics (Heikkinen et al., 2007); that is, an action researcher must give space to different voices and interpretations of the same events. Going further, Bradbury $(2015$, p. 1) alludes to it plainly by affirming that "action research is a pragmatic co-creation of knowing with, not on, people"; a democratic claim that may be emphasized using narratives. Indeed, the link between the rela-tional character of narratives and democratic participation in action research may be seen as one in which the former acts as a facilitator of the latter. The ensuing focus of narratives on integrating cooperatively others' conversations encourages friendly attitudes, a certain kind of love that leads to give up of the self to become part of the other. Such empathy-laden narrative process demands a willingness to listen by those who participate in the course of understanding. As a consequence, social experience studied through narrative becomes shared experience, and this can enable democratic participation to function as it should.

\section{Language}

Both narrative knowing and narrative telling are formed with and through lan-guage. Language is used to express meaning; but it is also a medium of thought that influences how meaning is constructed and how it is expressed (Polkinghorne, 2005). Clark and Dear (1984) maintain that language is used to construct social reality. This is because words are not neutral. They carry with them a semantic field of potential meanings, which is partly governed by a social code and partly indi-vidualized by the unique characteristics of the person who utters or interprets a given word (Sholes, 1980). Language is, from this perspective, more than syntax and a lexicon. As Bruner (1991, p. 14) puts it, "language, after all, is contained within its uses".

Narrative uses language to make sense of subjective experience. However, as experience is more complex than can be articulated in a language-imposed 
structure, narrative itself becomes a figurative language that conveys more of felt meaning's complexity than literal expressions (Bruner, 1985; Polkinghorne, 2007; Ricoeur, 1984). Narrative then expands the meanings of literal language; it extends understanding of an experience by contextualizing it. In such contextualizations, both listeners and tellers co-operate when employing language in mutual agree-ment. The meanings of the words they choose result from their voluntary and friendly predisposition for empathizing with others (Andrews, 2008). This, as noted above, is very important in action research, because people's involvement is one of its main characteristic features (Reason \& Torbert, 2001).

As a participative approach that occurs in context (Bradbury, 2015; Rauch et al., 2014), action research can find in the figurative language of narrative an important vehicle for practical knowledge creation. Understanding the nuances of language in narrative is, however, essential for action researchers. For example, despite that narratives presume a use of language in the framework of friendly co-operative relations, it would be important to consider the possibility that con-flicting assumptions underlie the utilization of certain words (Gaventa \& Cornwall, 2001). In such cases, the participative potential of narrative language might be misused. Given this possibility, action researchers, in their efforts to develop co-operative and democratic forms of knowledge, would have to notice how nar-rative language is employed in the service of those who are often ignored in order to define reality.

Time and space

Time and space are both important contextual dimensions of the narrative method (Brockmeier, 2000) and important devices for narrative making and telling (Baynham, 2003). Narratives give shape to personal experiences, placing and con-textualizing them in times and places in which they have been lived. Sequence and order, space and place, are all interweaved to offer both teller and listener the sensibility of a reality through a unique narrative time-space.

Referring to narrative-time relation, scholars have recognized that both are so closely, even inextricably, bound that it is impossible to understand and narrate an experience unless time is part of the experience (Andrews, 2008; Brockmeier, 2000; Bruner, 1991; Polkinghorne, 1988; Ricoeur, 1984). For Bruner (1991), a narrative is an account of events that occur over time; it is irreducibly durative. Brockmeier (2000) notes that narrative time is time told, which entails experienced time, that is, time as a human meaning construction. This means that, with the narrative method, there is an interplay of positioning alternative views of experiences and possible beginnings, with possible ends related to current or future moments (Brockmeier, 2000; Polkinghorne, 1988; Ricoeur, 1984). Such temporal orientation might recall Aristotle's poetics, in which the unfolding of events and actions over time was viewed as a typical feature of narratives (and stories) (see Greenhalgh, Russell, \& Swinglehurst, 2005). However, narrative time should be understood not only as succession in time but also as change through time. Change encompasses 
and evokes a number of different forms and orders of time, creating a multi-layered weave of human temporality (Andrews, 2008). Narrative time points, then, towards a "narrative temporality" (Cunliffe, Luhman, \& Boje, 2004), where time is experi-enced subjectively as linear or fluid but constantly moving, bringing change. In the context of action research, this aspect turns out to be especially important. It can help us understand action research in a radically dynamic way, carrying greater clarity to its development orientation, as a work always in progress (Brydon-Miller et al., 2003).

The narrative method also works by using space and place to contextualize narrative construction and telling. The location of a narrative in a specific place allows us not only to frame its meaning but also to highlight its singularity (Clandinin \& Connelly, 1991). Indeed, place enables us to re-create the sensations felt within an experience and thereby becomes a marker of both the site of enact-ment and the experience itself. In this respect, action research, as a mode of inquiry that reclaims the sphere of praxis and stresses the relevance of practitioners' local knowledge (Bradbury Huang, 2010; Reason \& Torbert, 2001), may find in the spatial contextuality of narratives an opportunity to grasp different points of view, acknowledge differences, and push researchers' personal growth. In this light, the spatial dimension of narratives offers to action researchers a medium that may help them to understand the world that they are trying to change, con-sidering situational idiosyncrasies.

Narrative's properties versus conventional social science methods

We have suggested that narrative might be a powerful tool for action research. Nevertheless, as also noted, it is not without its critics. By highlighting the value of subjectivity in each experience, narratives suggest that the same phenomenon may mean different things to different people; and this might be seen as a weakness of interpretation, particularly compared with conventional logical positivism. The problem is well understood (Bruner, 1991, 2004; Clandinin \& Connelly, 1991; Freeman, 1997; Polkinghorne, 1988, 2005; Riessman, 2004) and arises from the property of narrative as a natural social phenomenon. This, in essence, makes it an alternative means of knowing, one that can be referred to as a "science of the imagination", as opposed to a "science of the concrete" (Bruner, 1991).

As Bruner (1991) explains, the power inherent in the use of logic and logical propositions has helped us learn about our experiences by providing explanations of how we come to construct and "explain" a world of nature in terms of causes, probabilities, and space-time manifolds. Traditionally, thought has been treated in the social sciences as an instrument of reason. In fact, effective thought has become synonymous with right reason, and its efficacy is measured against the laws of logic or induction (Bruner, 2004). The propositional knowing implies knowing "about" something intellectually, that is, in terms of ideas and theories. Such knowledge is expressed in propositions and statements that use language to assert facts about the 
world, laws that state generalizations about those facts and theories that organize those laws (Heron \& Reason, 2008). However, when our concern is with particular occurrences, human interactions, or personal life experiences, logical principles and laws cannot be used to organize them; they cannot explain their richness (Polkinghorne, 2007). It is in such cases that narratives demonstrate their greatest potential. Indeed, by bringing to us part of the context in which experiences occur, narratives can help us obtain a richer and better understanding of them; and for this reason, narrative is a valuable tool of methodologies inherently connected to the context, as is the case with action research. This may nevertheless be perceived as a disadvantage relative to the heightened objectivity of social science. We next highlight how an appropriate understanding of the features of narratives can help us use such features as analytical strengths.

An incomplete picture of a phenomenon versus a better understanding of processes

There is the "myth" that narratives offer an incomplete and selective picture of the reality. Bruner (1991) argues that the focus of narratives on particular experiences through participants' perceptions, in contrast to an "objective" observation of many experiences, has contributed to such "myth". This is seen as a weakness of using narratives as a method (Elliot, 2005). However, experiences are never complete. They are constantly being reshaped, reconfigured to fit cur-rent circumstances. This is the "knowing", the adaptation and linking of the past to better understand the present. Riessman (2004) explains that narratives do not mirror but refract the past. The "telling", on the other hand, engages with imagination and strategic interests to influence how researchers and co-researchers, as storytellers, choose to connect events and actions to make them meaningful and understandable for others. Moreover, it is also recognized that experiencing involves the unfolding of a personal story about actions and events, with perceptions and meanings changing over time (Andrews, 2008). In this sense, rather than viewing social phenomena as fixed and static, as some-thing that can be fully captured and explained, the narrative method demonstrates through its incompleteness the complexities inherent in the processes of human relationships.

Viewed in this light, the problem of the narrative method may not be incompleteness but of over-completeness. In fact, although the argumentative structure of narrative reasoning may not be as logically compelling as arguments that take a strict syllogistic form, the narrative argument can still persuade at both a noncognitive (emotional, moral) and a cognitive (intellectual) level by enabling an under-standing of the evoked meanings, human truths, and significances that objects or entities may have (Van Manen, 1994). This, in fact, points to the principle of evocativeness, which has been recognized as a sign of quality in action research processes and reports based on narratives (Heikkinen et al., 2007, 2012). It stresses the artistic and evocative aspects of research narratives, such as aesthetics, 
creativity, interpretive vitality and expressive voice (Heikkinen et al., 2007). All these aspects are important because a great part of the attraction of narrative for action researchers is related to how it allows for the development of the living knowledge with which action research is concerned. As a methodological approach, action research is not so much concerned with structuring the problem studied in the first place but, above all, with its resolution, even though resolutions were only partial or only resulted in new questions (Gustavsen, 2003; Somekh, 2006). In this sense, the incompleteness of narratives might also serve as a man-festation of the practicality of action research. The dialogue between narrative knowing and telling, albeit highly subjective, thus provides considerable theoretical purchase on the diverse meanings surrounding a phenomenon, as it builds bridges with the emergent and developmental processes of action research.

(De)contextualizing actions and events versus

(re)contextualizing experiences

As noted above, context is a critical narrative framework. By framing an experience in context, we endow it with a particular meaning. Nonetheless, whilst the ambivalence extant in narrative is often seen as a research problem, it may also become a positive feature, especially when used in action research. This is because it provides us with clues about the nature of meanings and, more importantly, how they are developed. We can then use context to help explain meanings and how events and circumstances are imbued with them. We might, for example, discover why one context, and not another, can become meaningful and, most interestingly, why and how. But we might also ascertain how the narrator and audience are involved in the context and participate in actively (re)contextualizing experiences, consequently allowing the emergence of new knowledge. Context, in this wider perspective, is more than a situational variable; it is an aspect of the explanatory power of narrative. This applies to both aspects of narratives: making sense for the self - narrative knowing; and narrative telling, where sense is provided for others. In these ways, we can see how knowledge and practical solutions are co-created from context and circumstances.

From this point of view, contextual framing and resulting narrative differences render the narrative method, rather than problematic, an appropriate means by which action research can articulate its participatory worldview. Particularly, the contextual fluidity of narratives facilitates a move beyond the limited idea of context to the notion of the context as always emergent, interactive, thus enabling the participative orientation of action research to be put into practice. An exam-ple can be found in the study of social entrepreneurship (Diochon \& Anderson, 2011), especially in comparisons between developing and developed countries (Karanda \& Toledano, 2012). It is clear that people in different contexts hold quite different views about what it means to be a social entrepreneur and how to respond to these meanings. People's narratives mirror the diverse meanings of the problem studied, understood on the basis of their own contextual sense-making. 
On this point, the narratives brought to the research process can help achieve the practical outcomes of action research. In fact, action researchers would ideally involve all stakeholders in the problem investigated, as action research itself is focused on the interests of those immediately concerned (Reason \& Bradbury, 2001). We must, nonetheless, be mindful in narrative analysis of the subjectivities inherent in our own role as narrative listener. In some manner, the researcher becomes part of the context of the narrative, so that $\mathrm{s} /$ he will also impact action research processes and results.

The relevance of an experience versus discovering the importance of (ir)relevant aspects of a phenomenon

Another problem associated with the use of the narrative method arises from the idea that it might allow for the identification of the critical or causal factor, or event, in a phenomenon. Using the narrative method with such purpose would put us in a critical challenge: we may not be able to distinguish what is important from what is mere embellishment resulting from the sense-making and telling of an experience. The amount of detail involved in an experience can also be a disad-vantage of the narrative method, as tales must be adapted to the limitations of space and time in analysis and publication (Czarniawska, 2007). This, indeed, is a problem with most qualitative analysis, that is, the dilemma of finding what we are looking for, coupled with the issue of what is included and what is left out. Nonetheless, it can also be a boon to such work.

In comparison with a positivistic approach, where "variables" are predeter-mined by the researcher, narrative is an invitation to the informant to select the aspects they consider relevant for their own understanding, with stories framed to communicate that importance to others. This freedom in reflection has the advantage of identifying unanticipated explanatory elements, relationships or influences that can lead to new understandings and theories. In this way, narrative allows for a redefinition and identification of the relevance of any aspect, allowing any aspects, events or circumstances that initially did not seem relevant to become significant. This highlights a key strength of the narrative method: it shows how the importance of an experience may lie not only in the experience itself but also in the way that we think and talk to others about it. In other words, events may take on significance only as they are talked about and analysed among partners. In the context of action research, this aspect of the narrative method may serve to indicate the democratic nature of the action research processes. In fact, it may help make the diverse perspectives from which know-ledge is created explicit and even enable participation by the underprivileged. In addition, establishing what is included and what is left out of a narrative would be useful for action researchers, in particular, because words not spoken might shed light on the oppressed voices that action research tries to hear and consider (Bray et al., 2000; Pushar \& Clandinin, 2009); such words will then have the same importance as words spoken. 


\section{Conclusions}

We have sought to analyse the narrative method in the context of action research to try to improve our understanding of it from theoretical and practical points of view. In particular, we have focused on the ontological patterns, substantial elements and properties that characterize the use of narratives within the framework of social action research to clarify some of the problems that researchers may face in employing narratives. We argued that the narrative method should recognize and exploit the strengths of narrative as practice, and show how a clearer awareness of the duality of knowing and telling can be useful in utilizing the narrative method and illuminating its use in action research.

Based on our reflections, we have concluded that a key point of narratives lies in their rhetorical power. This faculty of narratives serves to provide understand-able explanations of the experiences that individuals undergo in their relation-ships as members of a society. In this sense, it is important to emphasize that the understanding that comes from the narrative process is found not within a person but in the interactions that people have with others. For this reason, we recognize that knowledge and understanding are always co-created. With this recognition, we wish to highlight two relevant aspects. The leading aspect has to do with the fact that the narrative method is a form in which people, cooperatively, co-create knowledge - i.e. an improved understanding of a phenomenon - and, consequently, a new social reality. The narrative method is thus a powerful tool for action research in the sense that it facilitates changes in knowledge, policy and practice (Pettit, 2010). The other aspect emerges from the co-creative nature linked with narratives. As a co-creative process, the application of the narrative method requires commitment among people in order to negotiate understandable meanings of their experiences in the social world. Such commitments, from our point of view, are possible only in the context of empathic relationships established among individuals. In analysis and in practice, this means that each person involved in a narrative process should develop an ability to put him/herself in the place of others. This highlights that we are never alone in the narrative process or in any process of action research. Accordingly, if we want to make full use of narrative as a method of inquiry in action research, we should also attend to the relationships that we maintain with ourselves and others.

\section{Acknowledgements}

We would like to thank Editors and the anonymous reviewers for their constructive feed-back and insightful comments throughout the process of revising the paper. Also, the author(s) would also like to thank Dr. Michelle Redman-MacLaren for leading the review process of this article. Should there be any comments/reactions you wish to share, please bring them to the interactive portion of our blog on the associated $A R+1$ ActionResearchPlus website: http://actionresearchplus.com. 


\section{References}

Adelman, C. (1993). Kurt Lewin and the origins of action research. Educational Action Research, $1(1), 7-24$.

Andrews, M. (2008). Never the last word: Revisiting data. In M. Andrews, C. Squire, \& M. Tamboukou (Eds.), Doing narrative research (pp. 86-101). London, UK: Sage Publications.

Attard, K. (2012). The role of narrative writing in improving professional practice. Educational Action Research, 20(1), 161-175.

Barthes, R. (1977). Introduction to the structural analysis of narratives. In S. Heath (Ed.), Imagemusic-text (pp. 79-124). New York, NY: Hill \& Wang.

Baynham, M. (2003). Narratives in space and time: Beyond "backdrop"' accounts of nar-rative orientation. Narrative Inquiry, 13(2), 347-366.

Bochner, A. P. (2012). On first-person narrative scholarship: Autoethnography as acts of meaning. Narrative Inquiry, 22(1), 155-164.

Boje, D. M. (2011). The quantum physics of storytelling. New Mexico: New Mexico State University.

Boog, B. W. (2003). The emancipatory character of action research, its history and the present state of the art. Journal of Community \& Applied Social Psychology, 13(6), 426-438.

Bradbury, H. (2015). Introduction to the handbook of action research. In H. Bradbury (Ed.), Handbook of action research, 3e (pp. 1-13). London, UK: Sage Publications.

Bradbury Huang, H. (2010). What is good action research?. Action Research, 8(1), 93-109.

Bray, J. J., Lee, J., Smith, L. L., \& Yorks, L. (2000). Collaborative inquiry in practice. Thousand Oaks, CA: Sage Publications.

Brockmeier, J. (2000). Autobiographical time. Narrative Inquiry, 10(1), 51-73.

Bruner, J. S. (1985). The role of interactive formats in language acquisition. In J. P. Forgas (Ed.), Language and social situations (pp. 31-46). New York, NY: Springer-Verlag.

Bruner, J. S. (1991). The narrative construction of reality. Critical Inquiry, 18(1), 11-21.

Bruner, J. S. (2004). Life as narrative. Social Research, 71(3), 691-710.

Brydon-Miller, M., Greenwood, D., \& Maguire, P. (2003). Why action research? Action Research, 1(1), 9-28.

Burnes, B. (2004). Kurt Lewin and the planned approach to change: A re-appraisal. Journal of Management Studies, 41(6), 977-1002.

Clandinin, D. J., \& Connelly, F. M. (1991). Narrative and story in practice and research. In D. Scho"n (Ed.), The reflective turn: Case studies in and on educational practice (pp. 258-281). New York, NY: Teachers College Press.

Clark, G. L., \& Dear, M. (1984). State apparatus: Structures and language of legitimacy. New York, NY: Allen and Unwin Inc. 
Colombo, M. (2003). Reflexivity and narratives in action research: A discursive approach. Qualitative Social Research, 4(2). Retrieved from www.qualitative-research.net/index. php/fqs/article/view/718.

Cunliffe, A. L., Luhman, J. T., \& Boje, D. M. (2004). Narrative temporality: Implications for organizational research. Organization Studies, 25(2), 261-286.

Czarniawska, B. (2007). Narrative Inquiry in and about organizations. In D. J. Clandinin (Ed.), Handbook of narrative inquiry. Mapping a methodology (pp. 383-404). London: Sage Publications.

Diochon, M., \& Anderson, A. R. (2011). Ambivalence and ambiguity in social enterprise: Narratives about values in reconciling purpose and practices. International Entrepreneurship and Management Journal, 7(1), 93-109.

Elliot, J. (2005). Using narrative in social research. Qualitative and quantitative approaches. London, UK: Sage Publications.

Eriksson, P., \& Kovalainen, A. (2015). Qualitative methods in business research: A practical guide to social research. London, UK: Sage Publications.

Fisher, W. R. (1984). Narration as a human communication paradigm: The case of public moral argument. Communication. Monographs, 51, 1-23.

Freeman, M. (1997). Why narrative? Hermeneutics, historical understanding, and the significance of stories. Narrative Inquiry, 7, 169-176.

Gaventa, J., \& Cornwall, A. (2001). Power and knowledge. In P. Reason, \& H. Bradbury (Eds.), Handbook of action research: Participative inquiry and practice (pp. 70-80). London, UK: Sage Publications.

Gergen, K. J., \& Gergen, M. G. (1988). Narrative and the self as relationship. Advances in Experimental Social Psychology, 21, 17-56.

Grant, A., \& Ken, D. (2016). Action research as a leadership strategy for innovation: The case of a global high-technology organisation. International Journal of Action Research, 12(1), 8-37.

Greenhalgh, T., Russell, J., \& Swinglehurst, D. (2005). Narrative methods in quality improvement research. Quality and Safety Health Care, 14, 443-449.

Greenwood, D. J. (2015). Evolutionary systems thinking: What Gregory Bateson, Kurt Lewin, and Jacob Moreno offered to action research that still remains to be learned. In H. Bradbury (Ed.), Handbook of action research, 3e (pp. 425-433). London, UK: Sage Publications.

Greenwood, D. J., \& Levin, M. (2007). Introduction to action research. Social research for social change. Thousand Oaks, CA: Sage Publications.

Grobstein, P. (2005). Revisiting science in culture: Science as story telling and story revising. Journal of Research Practice, 1(1), 1-18.

Gunz, J. (1996). Jacob L. Moreno and the origins of action research. Educational Action Research, 4(1), 145-148.

Gustavsen, B. (2003). New forms of knowledge production and the role of action research. Action Research, 1(2), 153-164.

Harding, S. (1986). The science question in feminism. Milton Keyness, UK: OUP.

Hardy, B. (1968). Toward a poetics of fiction. Novel, 2(1), 5-14.

Heikkinen, H. L. T., Huttunen, R., \& Syrja“la“, L. (2007). Action research as narrative: Five principles for validation. Educational Action Research, 15(1), 5-19.

Heikkinen, H. L. T., Huttunen, R., Syrja“la“, L., \& Pesonen, J. (2012). Action research and narrative inquiry: Five principles for validation revisited. Educational Action Research, 20(1), 5-21. 
Heron, J. (1988). Validity in co-operative inquiry. In P. Reason (Ed.), Human inquiry in action: Developments in new paradigm research (pp. 40-59). London, UK: Sage Publications.

Heron, J., \& Reason, P. (2008). Extending epistemology with a co-operative inquiry. In P. Reason, \& H. Bradbury (Eds.), Handbook of action research (pp. 366-380). London, UK: Sage Publications.

Hockley, J., Froggatt, K., \& Heimerl, K. (2013). Action research: An overview. In J. Hockley, K. Froggatt, \& K. Heimerl (Eds.), Participatory action research in pallia-tive care: Actions and reflections (pp. 3-14). Oxford: Oxford University Press.

Hosking, D. M. (2004). Change works: A critical construction. In J. Boonstra (Ed.), Dynamics of organizational change and learning. Chichester: Wiley.

Jamal, F., Bertotti, M., Lorenc, T., \& Harden, A. (2015). Reviewing conceptualisations of community: Reflections on a meta-narrative approach. Qualitative Research, 15(3), 314-333.

Karanda, C., \& Toledano, N. (2012). Social entrepreneurship in South Africa: A different narrative for a different context. Social Enterprise Journal, 8(3), 201-215.

Leitch, R., \& Day, C. (2000). Action research and reflective practice: Towards a holistic view. Educational Action Research, 8(1), 179-193.

Lincoln, Y., \& Guba, E. (1985). Naturalistic inquiry. London, UK: Sage Publications.

MacIntyre, A. (1981). After virtue. Notre Dame, IN: Notre Dame University Press.

McTaggart, R. (1994). Participatory action research: Issues in theory and practice. Educational Action Research, 2(3), 313-337.

Morgan, G. (1980). Paradigms, metaphors, and puzzle solving in organization theory. Administrative Science Quarterly, 25(4), 605-622.

Morgan, G., \& Smircich, L. (1980). The case for qualitative research. Academy of Management Review, 5(4), 491-500.

Muncey, T. (2010). Creating autoethnographies. London, UK: Sage Publications.

Pettit, J. (2010). Learning to do action research for social change. International Journal of Communication, 4, 820-827.

Polkinghorne, D. E. (1988). Narrative knowing and the human sciences. New York, NY: State University of New York Press.

Polkinghorne, D. E. (2005). Language and meaning: Data collection in qualitative research. Journal of Counseling Psychology, 52(2), 137-145.

Polkinghorne, D. E. (2007). Validity issues in narrative research. Qualitative Inquiry, 13(4), 471486.

Pushar, D., \& Clandinin, J. D. (2009). The interconnections between narrative inquiry and action research. In S. Noffke, \& B. Somekh (Eds.), The Sage handbook of educational action research (pp. 290-300). London: Sage Publications.

Rauch, F., Schuster, A., Stern, T., Pribila, M., \& Townsend, A. (2014) (Eds.) Promoting change through action research. Rotterdam: Sense Publishers.

Reason, P., \& Bradbury, H. (2001). Introduction: Inquiry and participation in search of a world worthy of human aspiration. In P. Reason, \& H. Bradbury (Eds.), Handbook of action research: Participative inquiry and practice (pp. 1-14). Thousand Oaks, CA: Sage Publications.

Reason, P., \& Torbert, W. R. (2001). The action turn: Toward a transformational social science. Concepts and Transformations, 6(1), 1-37.

Ricoeur, P. (1984). Time and narrative (Vol. 1). Chicago: University Chicago Press. 
Riessman, C. K. (2004). Narrative analysis. In M. S. Lewis-Beck, A. Bryman, \& T. Futing Liao (Eds.), Encyclopedia of social science research methods (pp. 705-709). Newbury Park, CA: Sage Publications.

Schein, E. H. (1996). Kurt Lewin's change theory in the field and in the classroom: Notes towards a model of management learning. Systems Practice, 9(1), 27-47.

Scho"n, D. (1983). The reflective practitioner. How professional think in action. New York, NY: Basic Books.

Sholes, R. (1980). Language, narrative, and anti-narrative. Critical Inquiry, 7(1), 204-212.

Shotter, J. (1984). Social accountability and selfhood. Oxford, UK: Blackwell.

Somekh, B. (2006). Action research: A methodology for change and development. Buckingham, UK: McGraw-Hill Education.

Stokols, D. (2006). Toward a science of transdisciplinary action research. American Journal of Community Psychology, 38, 63-77.

Swidler, A. (1986). Culture in action: Symbols and strategies. American Sociological Review, 51(2), 273-286.

Van Manen, M. (1994). Pedagogy, virtue, and narrative identity in teaching. Curriculum Inquiry, 24(2), 135-170.

Walker, M. (2007). Action research and narratives: Finely aware and richly responsible. Educational Action Research, 15(2), 295-303.

White, H. (1980). The value of narrativity in the representation of reality. Critical Inquiry, 7(1), 5-27.

\section{Author biographies}

Nuria Toledano is Associate Professor of Entrepreneurship at the University of Huelva, Spain. Her main research interest is on narratives, social and ethical entre-preneurship, entrepreneurship education and support programs for entrepreneur-ship in underdeveloped areas, where she has action research and community development experiences.

Alistair R Anderson is Professor of Entrepreneurship and Director of the Centre for Entrepreneurship at the Robert Gordon University in Aberdeen, UK. His research interests are primarily in the areas of entrepreneurship and small business, social aspects of entrepreneurship, and qualitative methodologies. He is currently the Editor of Entrepreneurship and Regional Development and Editorial Member Board of a number of journals. 